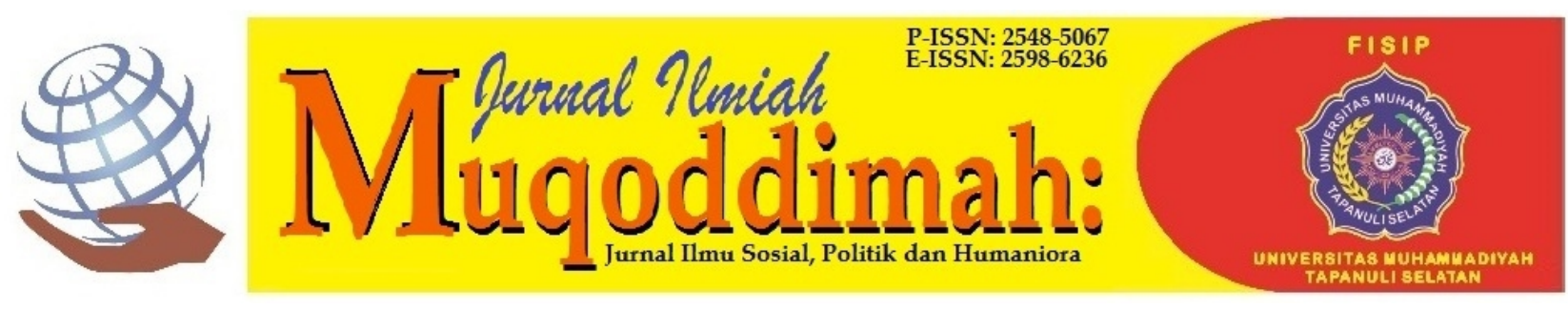

\title{
Evaluasi Pembangunan Desa Berdasarkan Indeks Desa Membangun
}

\author{
Agus Nyoman Astika1), Nyoman Sri Subawa2) \\ Program Studi Administrasi Publik, Universitas Pendidikan Nasional ${ }^{1)}$ \\ Program Studi Manajemen, Universitas Pendidikan Nasional'2) \\ Jalan Waturenggong No. 164 Panjer, Denpasar, Bali, Indonesia \\ agusman.astika@gmail.com¹) \\ shribawa@undiknas.ac.id²)
}

\begin{abstract}
Abstrak
Undang Undang Desa memberikan pandangan baru terhadap pembangunan desa. Pemerintah mengeluarkan Indeks Desa Membangun yang menilai tingkat kemandirian desa berdasarkan aspek sosial, ekonomi dan lingkungan sebagai peta pembangunan desa. Desa Penatahan telah melaksanakan tahapan pembangunan desa. Akan tetapi terjadi penurunan status kemandirian desa berdasarkan pemutakhiran Indeks Desa Membangun tahun 2016-2019. Penelitian ini dilakukan untuk mengetahui tahapaan pembangunan yang telah dilakukan Desa Penatahan, untuk mengetahui faktor pendukung dan penghambat pelaksanaan pembangunan di Desa Penatahan dan dampak pelaksanaan pembangunan desa terhadap tercapainya tujuan Desa Penatahan serta mengevaluasinya. Penelitian dilakukan secara deskriptif kualitatif dengan sumber data dari dokumentasi dan wawancara. Hasil penelitian ini adalah : (1) tahapan pelaksanaan pembangunan di Desa Penatahan tidak sesuai peraturan perundangan; (2) pembangunan yang dilaksanakan mempengaruhi ketercapaian tujuan pemangunan Desa Penatahan; (3) Tata kelola pemerintahan desa mempengaruhi keberhasilan pembangunan; dan (4) tidak adanya Pendapatan Asli Desa menyebabkan adanya ketergantungan anggaran pembangunan.
\end{abstract}

Kata kunci: evaluasi, indeks desa membangun, pembangunan desa

\begin{abstract}
The Village Law Law provides a new perspective on village development. The government issues a Developing Village Index which assesses the level of village independence based on social, economic and environmental aspects as a village development map. Penatahan Village has carried out the village development stages. However, there was a decline in the status of village independence based on the updating of the 2016-2019 Developing Village Index. This research was conducted to determine the stages of development that have been carried out by Penatahan Village, to determine the supporting and inhibiting factors for the implementation of development in Penatahan Village and the impact of the implementation of village development on the achievement of the objectives of Penatahan Village and to evaluate them. The research was conducted in a descriptive qualitative manner with data sources from documentation and interviews. The results of this research are: (1) the stages of development implementation in Penatahan Village are not in accordance with the laws and regulations; (2) the implemented development affects the achievement of the development objectives of Penatahan Village; (3) Village governance affects development success; and (4) the absence of Village Original Income causes dependence on the development budget.
\end{abstract}

Key words: evaluation, developing village index, village development

Volume 5, Nomor 2, Agustus 2021 


\section{PENDAHULUAN}

Dikeluarkannya peraturan perundangan yang mengatur tentang desa memberikan sudut pandang baru tentang pembangunan Desa, dimana desa diberikan peran menjadi subjek dalam pembangunan. Disebutkan bahwa pembangunan desa adalah suatu usaha untuk mewujudkan masyarakat desa yang sejahtera dengan memenuhi kebutuhan sosial dasar serta mengoptimalkan potensi desa untuk ekonomi lokal dan pemanfaatan lingkungan berkelanjutan. UU Desa menguatkan posisi Desa dengan memberikan penegasan terhadap kewangan Desa yang meliputi kewenangan lokal skala Desa dan kewenangan hak asal usul. Dengan kewenangan tersebut, Desa memiliki hak penuh untuk mengelola pembangunan di daerahnya masing-masing dengan dasar musyawarah Desa sebagai pemegang keputusan tertinggi. Dengan kondisi ini, partisipasi masyarakat untuk memajukan desanya menjadi salah satu kunci menuju Desa Mandiri selain dari peran pemerintah Desa dalam melaksanakan pembangunan. Konsep inilah yang disebut dengan Desa Membangun. Pembangunan Desa sendiri meliputi tahap perencanaan, pelaksanaan, pengawasan dan pertanggungjawaban yang berpedoman pada Permendagri 114/2014 tentang Pedoman Pembangunan Desa.

Untuk menentukan lokus sasaran pengentasan Desa Tertinggal, pemerintah mengembangkan Indeks Desa Membangun (IDM) yang menjadi peta pengembangan pembangunan Desa. IDM terdiri dari Indeks Ketahanan Sosial (IKS); Indeks Ketahanan Ekonomi (IKE); dan Indeks Ketahanan Lingkungan (IKL), yang merupakan terjemahan dari kebutuhan pembangunan yang tertuang pada pasal 74 ayat (2) UU Desa. Ketiga indeks ini, sejalan dengan konsep pembangunan berkelanjutan yaitu pembangunan yang meliputi dimensi sosial, ekonomi, dan berwawasan lingkungan hidup berkelanjutan. Berdasarkan penilaian kondisi lapangan sesuai indikator masing-masing indeks, menghasilkan status kemajuan dan kemandirian Desa yang terdiri dari Desa Mandiri, Desa Maju, Desa Berkembang, Desa Tertinggal dan Desa Sangat Tertinggal. Klasifikasi tersebut sebagai penegasan atas status kemandirian desa dan intervensi yang perlu diberikan.

Desa Penatahan merupakan salah satu desa di Kecamatan Penebel Kabupaten Tabanan, yang terdiri dari 6 Banjar Dinas yaitu Banjar Dinas Mongan, Bedugul, Penatahan Kaja, Penatahan Kelod, Kekeran dan Banjar Dinas Tegayang. Desa Penatahan terletak di sebelah utara Kabupaten Tabanan dengan geografis pegunungan yang sebagaian besar wilayahnya dimanfaatkan untuk pertanian. Berdasarkan data Profil Desa, dari 34.791 Ha Luas Wilayah Desa Penatahan, seluas $20.900 \mathrm{Ha}(60 \%)$ merupakan tanah persawahan. Dari kondisi ini dapat dilihat bahwa pertanian adalah potensi terbesar yang dimiliki oleh Desa Penatahan. Selain potensi pertanian, Desa Penatahan juga memiliki potensi wisata berupa air panas alami/natural hot spring.Dalam pengembangan ekonomi desa, Desa Penatahan juga memiliki Badan Usaha Milik Desa (BUM Desa) yang bergerak dibidang penyediaan sarana upakara dan penyediaan sarana pertanian.

Potensi yang dimiliki tersebut ternyata tidak mampu menjadikan Desa Penatahan menjadi Desa Mandiri berdasarkan Indeks Desa Membangun (IDM). Berikut adalah nilai Indeks Desa Membangun (IDM) Desa Penatahan tahun 2016, 2018 dan 2019 berdasarkan SK Dirjen PPMD Kemendes PDTT. 


\section{Tabel 1.}

Indeks Desa Membangun (IDM) Desa Penatahan Kecamatan Penebel Kabupaten Tabanan

\begin{tabular}{llllll}
\hline Tahun & \multicolumn{1}{c}{ IKS } & \multicolumn{1}{c}{ IKE } & \multicolumn{1}{c}{ IKL } & \multicolumn{1}{c}{ IDM } & Status Kemandirian \\
\hline 2016 & N/A & N/A & N/A & 0.7400 & Maju \\
2018 & 0.75430 & 0.73330 & 0.6000 & 0.69587 & Berkembang \\
2019 & 0.81710 & 0.63330 & 0.53330 & 0.66130 & Berkembang \\
\hline
\end{tabular}

Sumber : SK Dirjen PPMD Kementerian Desa PDTT

Dari tabel 1, dapat kita lihat bahwa Desa Penatahan Kecamatan Penebel terus mengalami penurunan nilai IDM sebesar 0,0441 pada tahun 2018 dan 0,0346 pada tahun 2019. Penurunan Indeks ini menyebabkan status Desa Penatahan turun dari Desa Maju menjadi Desa Berkembang pada tahun 2018, dan pada tahun 2019 tetap berstatus Desa Berkembang. Walaupun terjadi peningkatan aspek ketahanan sosial, akan tetapi ketahanan ekonomi dan lingkungan mengalami penurunan. Penurunan nilai Indeks Desa Membangun menunjukkan penurunan pada kualitas pemenuhan ekonomi masyarakat dan kualitas lingkungan. Penurunan ini dipengaruhi oleh pelaksanaan pembangunan sesuai kewenangannya. Sebagaimana penelitian yang dilakukan oleh Muhtarom, dkk (2018), bahwa kegiatan yang dilakukan oleh desa memberikan pengaruh terhadap perubahan nilai indeks komposit IDM. Sebagai Desa yang memiliki potensi wisata alam dan potensi pertanian, penurunan pada kedua indeks ini menunjukkan ketidaksesuaian dengan definisi pembangunan khususnya pembangunan berkelanjutan serta tujuan pembangunan desa sebagaimana disebutkan pada pasal 78 Undang Undang Desa. Pembangunan sebagai suatu proses perubahan yang secara sadar dan terus menerus untuk mencapai kemajuan dan perbaikan hidup yang lebih baik menuju tujuan yang diinginkan, sehingga dalam pembangunan terkandung unsur perubahan, tujuan, dan potensi dengan memberi kesempatan aspirasi masyarakat menemukan titik tengah untuk mencapai tujuan bersama (Agus Suryono, 2010). Potensi yang dimiliki oleh desa dikelola untuk menunjang tercapainya tujuan pembangunan desa (Bakti, 2018). Selain itu, tata kelola pemerintahan desa dan partisipasi masyarakat juga memberikan pengaruh terhadap pembangunan dan perbaikan hidup masyarakat desa (Setyowati, 2019).

Menurut Tay dan Rusmiwari (2019), terdapat faktor pendukung dan penghambat dalam implementasi pembangunan berkelanjutan di desa. Faktor pendukung meliputi ketersediaan sumber daya alam yang melimpah, dan sumber daya manusia yang sudah mumpuni di bidang pembangunan; adamya kepastian hukum atau peraturan yang mengatur tentang kebijakan pembangunan berkelanjutan; serta tingkat partisipasi masyarakat yang tinggi dan kesadaran masyarakat akan pentingnya pembangunan. Sedangkan faktor yang menghambat meliputi kurangnya wawasan dan pola pikir tentang pentingnya pembangunan berkelanjutan, kurangnya partisipasi masyarakat, gejala alam yang menghambat pembangunan infrastruktur, serta pro kontra masyarakat yang menghambat pemerintah desa dalam pengambilan keputusan.

Untuk itu, pada penelitian ini akan berupaya menjelaskan tahapan pelaksanaan pembangunan di Desa Penatahan Kecamatan Penebel Kabupaten Tabanan yang nilai IDM-nya terus mengalami penurunan, untuk mengetahui faktor pendukung dan penghambat pembangunan di Desa Penatahan serta dampak pelaksanaan pembangunan di Desa Penatahan terhadap pencapaian tujuan pembangunan dan mengevaluasinya dengan dimensi konsistensi, transparansi, akuntabilitas, keadilan, partisipatif, efektivitas dan efisiensi (Ramdhani, 2016). 


\section{METODE}

Penelitian dilakukan dengan pendekatan kualitatif deskriptif. Penelitian dilaksanakan di Desa Penatahan, Kecamatan Penebel, Kabupaten Tabanan. Pengumpulan data dilakukan dengan wawancara mendalam dan dokumentasi. Informan ditentukan secara purposive sampling. Analisis Data dilakukan dengan mengumpulkan data dari arsip dokumen pembangunan di Desa Penatahan dan peraturan perundangan yang berlaku serta dari wawancara dengan informan. Selanjutnya data dipilah dan disajikan untuk diambil kesimpulan

\section{HASIL DAN PEMBAHASAN}

Pelaksananaan Pembangunan Desa di Desa Penatahan berpedoman pada Permendagri tentang Pedoman Pembangunan Desa. Tahapan pelaksanaan pembangunan desa yang dilakukan oleh Desa Penatahan meliputi tahap Penyusunan RPJM Desa, Penyusunan RKP Desa, Penyusunan APB Desa, Pelaksanaan APB Desa/Pembangunan Desa, Pertanggungjawaban Pelaksanaan Pembangunan Desa.

Penyusunan RPJM Desa Penatahan Tahun 2015-2021, tahap yang dilakukan Desa Penatahan sebagai berikut:

1) Rapat pembentukan Tim Penyusun RPJM-Des yang dihadiri unsur Perbekel, BPD, Perangkat Desa, LPM dan Bendesa Adat pada tanggal 21 Oktober 2015. Tim tersebut ditetapkan dengan SK Perbekel Desa Penatahan Nomor 06 Tahun 2015 tentang Pembentukan Tim Penyusunan RPJM-DES yang ditandatangani pada tanggal 21 Oktober 2015.

2) Penyusunan Draft RPJM DES Desa Penatahan Tahun 2015-2020 dilaksanakan secara internal oleh Tim Penyusun pada tanggal 21 Oktober 2015.

3) Musyawarah Desa memabahas dan menetapkan Draft RPJM-Des yang telah dibuat oleh Tim Penyusun pada tanggal 21 Oktober 2015, dimana berdasarkan dokumentasi pelaksanaan musyawarah desa penyusunan RPJM DES, undangan dibuat pada tanggal 21 Oktober 2015 oleh Perbekel Desa Penatahan dan mengundang BPD, Bendesa Adat, Pekaseh, Pengurus PKK Desa, Kelian Banjar Dinas, Bimas/Bhabinkamtibmas, Babinsa dan PPL.

$\mathrm{Hal}$ ini tidak sesuai dengan peraturan perundangan dimana seharusnya musyawarah desa dilaksanakan oleh BPD sehingga surat undangan seharusnya dibuat oleh Ketua BPD. Berdasarkan hasil wawancara dengan Anggota BPD dan Pendamping, bahwa pelaksanaan musyawarah desa tidak aktif dan lebih terkesan formalitas.Dokumen RPJM DES Desa Penatahan Tahun 2015-2020 juga tidak ditetapkan dengan Peraturan Desa, sehingga tidak sesuai dengan standar yang berlaku.

Dari kondisi ini dapat kita lihat bahwa proses penyusunan RPJM DES Desa Penatahan Tahun 2015-2020 tidak sesuai dengan peraturan perundangan serta prosesnya lebih dilakukan secara internal pemerintah desa. Arsip Dokumen yang ada dengan didukung oleh pernyataan Anggota BPD dan Pendamping, menunjukkan RPJM-Des Desa Penatahan disusun kurang maksimal dengan penyelesaian hanya satu hari dengan tahapan yang banyak.

Berdasarkan arsip dokumen penyusunan RKPDes Desa Penatahan telah disusun melalui Musdes terkait pencermatan RPJMDes kemudian dilanjutkan dengan mekanisme Musyawarah Perencanaan Pembangunana Desa (Musrenbangdes) terkait penyepakatan Draft RKPDes dan ditetapkan dengan Perdes tentang Rencana Kerja Pemerintah Desa pada bulan Desember setiap tahunnya. Musrenbangdes diikuti oleh Perangkat Desa, BPD, PKK, Lembaga Adat dan Perwakilan masyarakat miskin. Hal ini tidak sesuai perturan perundangan seharusnya Peraturan Desa tentang RKP Desa paling lambat bulan September.

Setelah RKP Desa Penatahan ditetapkan dengan Perdes, Pemerintah Desa Penatahan menyusun Anggaran Pendapatan dan Belanja Desa Penatahan sesuai dengan pagu anggaran dan kegiatan pada RKPDesa yang telah disepakati. Rancangan APBDesa Penatahan diinput pada aplikasi SISKEUDES yang dikelola secara resmi oleh Kementerian Dalam Negeri. Hasil 
input pada SISKEUDES di evaluasi oleh Camat Penebel berkoordinasi dengan Dinas Pemberdayaan Masyarakat dan Desa Kabupaten Tabanan. Setelah disetujui, APB Desa Penatahan ditetapkan dengan Peraturan Desa Penatahan tentang Anggaran Pendapatan dan Belanja Desa Penatahan pada bulan Desember setiap tahunnya. Hal ini telah sesuai dengan aturan yang ditetapkan pemerintah.

Pelaksanaan pembangunan Desa di Desa Penatahan lebih banyak pada pembangunan sarana prasana desa. Kondisi ini ditunjukkan pada realisasi belanja APBDesa Penatahan dari Tahun 2016-2019 dimana belanja tersebesar ada pada bidang pelaksanaan pembangunan.

Tabel 2.

Realisasi Belanja Desa Penatahan Tahun 2016-2019

\begin{tabular}{ccccc}
\hline Tahun & $\begin{array}{c}\text { Penyelenggaraan } \\
\text { Pemerintahan } \\
\text { Desa }\end{array}$ & $\begin{array}{c}\text { Bidang } \\
\text { Pelaksanaan } \\
\text { Pembangunan }\end{array}$ & $\begin{array}{c}\text { Bidang } \\
\text { Pembinaan } \\
\text { Kemasyarakatan }\end{array}$ & $\begin{array}{c}\text { Bidang } \\
\text { Pemberdayaan } \\
\text { Masyarakat }\end{array}$ \\
\hline $\mathbf{2 0 1 6}$ & 422.014 .049 & 749.742 .000 & 769.432 .500 & 227.345 .800 \\
$\mathbf{2 0 1 7}$ & 610.487 .488 & 1.475 .337 .000 & 176.556 .000 & 109.026 .900 \\
$\mathbf{2 0 1 8}$ & 625.997 .423 & 1.499 .960 .663 & 236.693 .500 & 133.528 .200 \\
$\mathbf{2 0 1 9}$ & 764.500 .602 & 1.059 .033 .932 & 954.179 .000 & 61.696 .520 \\
\hline
\end{tabular}

Sumber : Laporan Pertanggungjawaban Desa Penatahan Tahun 2016-2019

Dari tabel 2, dapat kita lihat bahwa fokus pelaksanaan pembangunan Desa Penatahan dari Tahun 2016 sampai dengan Tahun 2019 masih pada pembangunan sarana dan prasarana Desa. Dukungan anggaran terhadap lembaga kemasyarakatan yang ada di Desa Penatahan turun pada tahun 2017 (7\%) dan 2018 (10\%), kemudian meningkat pada tahun 2019 (34\%). Sedangkan untuk bidang pemberdayaan masyarakat terus berkurang dari tahun $2016(11 \%)$, 2017 (5\%), 2018 (5\%) dan $2019(2 \%)$.

Indeks Desa Membangun menilai kemandirian desa berdasarkan konsep pembangunan berkelanjutan, yakni dari aspek sosial, ekonomi dan lingkungan berkelanjutan. Pembangunan yang dilakukan oleh Desa Penatahan dari tahun 2016 sampai dengan tahun 2019 lebih fokus pada pembangunan sarana prasarana desa sehingga kondisi sarana prasarana sosial dasar pedesaan di Desa Penatahan yang meliputi pelayanan kesehatan, akses pendidikan, sarana umum, sarana permukiman menjadi semakin baik serta mendukung peningkatan nilai Indeks Ketahanan Sosial Desa Penatahan. Rendahnya anggaran pemberdayaan masyarakat yang digunakan untuk meningkatkan kemampuan masyarakat dalam memenuhi kebutuhan hidupnya, memberikan pengaruh terhadap menurunnya Indeks Ketahanan Ekonomi Desa Penatahan.

Pemanfaatan potensi untuk mencapai tujuan pembangunan tidak dilakukan di Desa Penatahan. Pertanian sebagai potensi terbesar Desa Penatahan tidak pernah tersentuh anggaran pembangunan sehaj tahun 2016 hingga tahun 2019.

Terkait dengan ekologi, pada APBDesa Penahatan Tahun 2016 hingga tahun 2018, hanya menganggarkan upah tenaga kebersihan. Tidak terdapat anggaran untuk mendukung lingkungan hidup. Desa Penatahan sampai saat ini tidak memiliki tempat pengelolaan sampah. Hal ini memberikan pengaruh terhadap penurunan nilai Indeks Ketahanan Lingkungan Desa Penatahan.

Berdasarkan arsip dokumen, Pertanggungjawaban pelaksanaan pembangunan desa dan realisasi APBDesa dilakukan dengan mekanisme musyawarah Desa yang dilaksanakan setiap bulan Januari yang dihadiri oleh Perangkat Desa dan BPD. Hal ini tidak sesuai dengan peraturan perundangan dimana seharusnya pelaksanaan musyawarah desa selain melibatkan unsur 
pemerintahan desa dan BPD, juga melibatkan unsur masyarakat atau tokoh masyarakat.

Dalam melaksanakan pemabangunan desa, Desa Penatahan memiliki faktor-faktor yang menhambat dan mendukung pelaksanaan pembangunan. Faktor penghambat tersebut terdiri dari :

1. Kelemahan dalam pendokumentasian data.

2. Anggaran yang terbatas tidak dapat memenuhi seluruh kebutuhan pembangunan.

3. Tingkat pastisipasi yang rendah.

4. Tata Kelola pemerintahan desa yang tidak sesuai peraturan perundangan.

Sedangkan faktor yang mendukung yaitu hubungan yang baik antara pemerintah desa dan BPD memperlancar proses penetapan dokumen-dokumen pembangunan desa meliputi Dokumen RPJM Desa, Peraturan Desa tentang RKP Desa, Peraturan Desa tentang APBDesa, dan Peraturan Desa tentang Pertanggungjawaban Pelaksanaan APBDesa walaupun dalam prosesnya tidak konsisten terhadap aturan perundangan yang berlaku. Hal ini menyebabkan tidak adanya hambatan dalam penyusunan dan pelaksanaan APBDesa

Desa Penatahan memiliki visi Desa "Terwujudnya Desa Penatahan yang BALIS, Berbudaya, Aman, Lestari, Indah dan Sejahtera". Untuk mewujudkan visi tersebut, disusun RPJM-Desa, RKPDesa dan APBDesa.

Indeks Ketahanan Sosial ini menjadi indikator keberhasilan tercapainya visi Desa Penatahan yang Berbudaya dan Aman serta misi kedua yaitu Meningkatkan keamanan masyarakat melalui Siskambling. Pada pemutakhiran status kemandirian desa tahun 2018 dan 2019, nilai Indeks Ketahanan Sosial Desa Penatahan mengalami peningkatan dari 0,75430 (2018) menjadi 0,81710 (2019). Peningkatan ini mengindikasikan perbaikan mutu pada pelayanan kesehatan, akses pendidikan, sarana prasarana perkumiman, dan modal sosial (solidaritas, toleransi, keamanan, ruang publik, kesejahteraan sosial). Selaras dengan fokus pembangunan pada APBDesa Penatahan dari tahun 2016 hingga tahun 2019 yang dominan anggaran untuk pelaksanaan pembangunan fasilitas sosial dasar pedesaan.

Indeks Ketahanan Ekonomi, menjadi indikator visi Desa Penatahan yang Sejahtera serta misi keempat yaitu meningkatkan kesejahteraan masyarakat melalui ekonomi yang kreatif. Kegiatan dari APBDesa yang menyentuh ekonomi kreatif untuk mewujudkan misi keempat meliputi pelatihan kelompok ekonomi kreatif dengan anggaran Rp.7.800.000,- pada tahun 2017. Di Desa Penatahan terdapat BUMDesa yang bergerak di bidang penjualan sarana upakara dan sarana pertanian dengan penyertaan modal sebesar Rp.200.000.000,- pada pembentukan tahun 2016. Pada tahun 2018, Pemerintah Desa Penatahan memberikan tambahan penyertaan modal ke BUMDesa sebesar Rp.25.000.0000,- untuk pengembangan usaha dalam rangka melayani Bantuan Pemerintah Non-Tunai, dimana BUMDesa Penatahan melayani Rumah Tangga Sasaran penerima Bantuan Pemerintah Non-Tunai dari Desa Penatahan, Desa Tengkudak, Desa Tegallinggah dan Desa Rejasa. Langkah peningkatan ekonomi yang dilakukan pemerintah desa belum menyentuh potensi terbesar desa Penatahan. Dari 344,04 Ha luas wilayah Desa Penatahan, 209 Ha merupakan lahan pertanian dan 64 Ha merupakan lahan perkebunan. Didukung dengan sebagian besar mata pencaharian penduduk Desa Penatahan sebagai petani (858 orang dari 1.446 orang golongan kerja). Kondisi ini selaras dengan penurunan nilai Indeks Ketahanan Ekonomi pada pemutakhiran tahun 2018 dan 2019, dari nilai 0,733330 (2018) menjadi 0,63330 (2019).

Indeks Ketahanan Lingkungan menjadi indikator keberhasilan untuk visi Desa Penatahan yang Lestari dan Indah serta misi ketiga yaitu Mewujudkan Desa yang bersih, Indah dan Lestari. Pada dokumen APBDesa Penatahan tahun 2016-2019 untuk kegiatan lingkungan berupa honor tenaga kebersihan di kantor desa, serta bantuan alat kebersihan kepada banjar-banjar dan anggaran tangang bencana tahun 2019. Desa Penatahan sendiri tidak memiliki fasilitas pengelolaan sampah sehingga tergantung pada penganggukatan sampah dari Pemerintah Kabupaten Tabanan. Kondisi ini selaras dengan penurunan nilai Indeks Ketahanan Lingkungan Desa Penatahan pada pemutakhiran tahun 2018 dan 2019, dari nilai 0,69587 (2018) menjadi 
$0,66130(2019)$.

Indeks Desa Membangun tidak mengukur pelaksanaan pemerintahan Desa sehingga keberhasilan tujuan Desa Penatahan terkait peningkatan mutu penyelenggaraan pemerintahan desa tidak dapat diukur dengan Indeks Desa Membangun. Langkah yang telah dilakukan yaitu melakukan kegiatan peningkatan kapasitas aparatur pemerintah desa dan BPD setiap tahunnya. Dengan dilakukang peningkatan kapasitas aparatur pemerintah desa, seharusnya pelaksanaan pembangunan dari tahap perencanaan, pelaksanaan dan pertanggungjawaban berjalan sesuai aturan. Akan tetapi dari arsip dokumen ditemukan pelaksanaan yang tidak sesuai aturan seperti musyawarah desa yang tidak melibatkan unsur masyarakat pada musyawarah desa pertanggungjawaban, penetapan Peraturan Desa tentang RKPDesa yang melebihi batas waktu. Dari laporan pertanggungjawaban APBDesa Penatahan setiap tahunnya, pada pekerjaan proyek fisik seperti pembangunan jalan dan gedung, seharusnya ada efisiensi anggaran bahan hasil dari negosiasi pengadaan, tetapi anggaran terealisasi habis tanpa adanya efisiensi anggaran.

Indeks Desa Membangun yang tidak mempertimbangkan dimensi penyelenggaraan pemerintahan desa dan keberadaan Pendapatan Asli Desa dalam menentukan tingkat kemandirian Desa. Dalam penelitian ini, tata kelola pemerintahan desa di Desa Penatahan yang dalam prosesnya ada tahapan yang tidak sesuai dengan peraturan perundangan mempengaruhi pembangungan akibat rendahnya partisipasi masyarakat dalam proses pelaksanaan pembangunan desa. Begitu pula dengan tidak adanya Pendapatan Asli Desa, kegiatan pembangunan di Desa Penatahan bergantung pada anggaran yang diberikan pemerintah pusat, provinsi dan kabupaten, sehingga kekurangan anggaran untuk mencapai visi, misi, tujuan, dan arah kebijakan tidak dapat dihindarkan.

Kebijakan pembangunan desa yang telah dilaksanakan oleh Desa Penatahan tahun 2016 - 2019 telah dilaksanakan serta memberikan pengaruh terhadap pencapaian tujuan Desa Penatahan. Pelaksanaan pembangunan tersebut perlu dievaluasi untuk dapat dijadikan acuan perbaikan dan peningkatan dalam rangka mengoptimalkan pencapaian tujuan pembangunan. Hasil evaluasi yang dilakukan berdasarkan dimensi evaluasi menurut Ramdhani (2016) sebagai berikut :

Konsistensi, Tahapan pelaksanaan pembangunan yang dilaksanakan di Desa Penatahan banyak menyimpang dari peraturan perundangan yang berlaku. Penyimpangan tersebut meliputi tahapan penyusunan RPJM Desa yang tidak sesuai, pelaksanaan musyawarah desa dan musyawarah perencanaan pembangunan desa yang tidak melibatkan unsur masyarakat, serta penetapan Peraturan Desa tentang RKPDesa yang melebihi batas waktu yang ditentukan. Sehingga dapat dikatakan bahwa tahapan pelaksanaan pembangunan desa di Desa Penatahan tidak konsisten.

Transparansi, Transparansi pembangunan desa masih hanya dalam bentuk pemasangan baliho yang berisi informasi gambaran umum APBDesa. Melibatkan masyarakat dalam musyawarah desa dan musyawarah perencanaan pembangunan desa yang merupakan bentuk transparansi dalam perencanaan pembangunan desa tidak dilakukan di Desa Penatahan. Sehingga dapat dikatakan transparansi pelaksanaan pembangunan di Desa Penatahan masih kurang.

Akuntabilitas, Pelaksanaan pembangunan desa di Desa Penatahan dipertanggungjawabkan setiap awal tahun pada tahun anggaran berikutnya melalui mekanisme musyawarah desa. Akan tetapi musyawarah desa yang dilakukan tidak melibatkan unsur perwakilan masyarakat sehingga tidak terdapat tahapan mempertanggungjawabkan pelaksanaan pembangunan kepada masyarakat.

Keadilan, Penyusunan perencanaan pembangunan desa di Desa Penatahan kurang melibatkan keterlibatan unsur masyarakat dan dilakukan dengan tahapan yang sangat singkat tanpa pencermatan kondisi lapangan, tidak dapat memberikan gambaran keadilan dalam pelaksanaan pembangunan desa.

Partisipatif, Kondisi pelaksanaan musyawarah desa dan musyawarah perencanaan 
pembangunan desa yang kurang aktif, terkesan formalitas dan tidak melibatkan unsur masyarakat menunjukkan rendahnya partisipasi pada pelaksanaan pembangunan desa di Desa Penatahan.

Efektivitas, Misi pertama Desa Penatahan yaitu Mewujudkan Pemerintahan Desa yang mandiri dan berwibawa berwawasan budaya diwujudkan dengan pelaksanaan kegiatan peningkatan kapasitas aparatur pemerintahan desa atau BPD setiap tahunnya. Misi kedua yaitu Meningkatkan keamanan masyarakat melalui Siskambling diwujudkan dengan pelatihan pecalang pada tahun 2016 dan pelatihan linmas pada tahun 2017 dan 2018. Misi ketiga yaitu Mewujudkan Desa yang bersih, Indah dan Lestari diwujudkan dengan menganggarkan jasa tenaga kebersihan setiap tahunnya. Misi keempat yaitu Meningkatkan kesejahteraan masyarakat melalui ekonomi yang kreatif diwujudkan dengan pelaksanaan pelatihan kelompok ekonomi kreatif pada tahun 2017 serta penyertaan modal BUMDesa. Akan tetapi potensi utama Desa Penatahan yaitu pertanian belum mendapatkan sentuhan dari pemerintah desa. Dilihat berdasarkan Indeks Desa Membangun, yang mengukur ketahanan sosial, ekonomi dan lingkungan, pencapaian misi ketiga tentang lingkungan dan misi keempat tentang ekonomi masyarakat dapat dikatakan tidak efektif karena nilai IKE dan IKL menurun pada pemutakhiran tahun 2018 dan 2019.

Efisiensi, Berdasarkan Indeks Desa Membangun yang terdiri dari tiga aspek yaitu sosial, ekonomi dan lingkunga, dilihat dari aspek IKS, penggunaan APBDesa untuk pembangunan sarana prasarana dasar pedesaan efisien meningkatkan nilai IKS pada pemutakhiran tahun 2018 dan 2019 secara signifikan. Sedangkan dilihat dari aspek ekonomi dan lingkungan, anggaran yang digunakan untuk kegiatan peningkatan ekonomi dan lingkungan tidak efisien karena pada pemutakhiran tahun 2018 dan 2019 nilai IKE dan IKL mengalami penurunan. Pemerintah Desa Penatahan melakukan penyertaaan modal ke BUMDesa akan tetapi dalam tiga tahun pengelolaan BUMDesa belum mampu memberikan Pendapatan Asli Desa, sehingga penyertaan modal ini dapat diaktakan belum efisien.

\section{SIMPULAN DAN SARAN}

Berdasarkan hasil penelitian dan pembahasan fokus permasalahan pada penelitian ini, maka dapat diambil simpulan sebagai berikut :

1. Desa Penatahan telah melakukan tahapan-tahapan pelaksanaan pembangunan Desa akan tetapi tidak sesuai dengan ketentuan pada peraturan perundangan.

2. Pembangunan desa yang dilakukan di Desa Penatahan memberikan pengaruh atas ketercapaian tujuan pembangunan desa yang tertuang dalam visi, misi, tujuan dan arah kebijakan pembangunan Desa Penatahan.

3. Tata kelola pemerintahan desa di Desa Penatahan yang tidak sesuai peraturan perundangan memberikan pengaruh terhadap pembangunan akibat rendahnya partisipasi masyarakat. Hal ini tidak diperhitungkan pada Indeks Desa Membangun dalam menentukan tingkat kemandirian desa.

4. Ketidakberadaan Pendapatan Asli Desa di Desa Penatahan menyebabkan ketergantungan pada anggaran yang diberikan pemeritnah pusat, provinsi dan kabupaten sehingga ada arah kebijakan yang tidak didukung kegiatan untuk dicapai. Hal ini tidak diper Hal ini tidak diperhitungkan pada Indeks Desa Membangun dalam menentukan tingkat kemandirian desa.

Berdasarkan hasil penelitian ini, peneliti dapat memberikan saran sebagai berikut :

1. Penyusunan dokumen perencanaan pembangunan desa yang meliputi RPJM Desa, RKP Desa, APB Desa, agar sesuai dengan peraturan perundangan yang berlaku, dalam hal tahapan yang dilalui, waktu pelaksanaan, serta stakeholder yang terlibat. Transparansi informasi penting dilakukan untuk meningkatkan partisipasi masyarakat. Keterlibatan masyarakat dari tahap perencanaan, pelaksanaan, pengawasan dan pertanggungjawaban penting untuk ditingkatkan, dimulai dengan mengundang unsur- 
unsur masyarakat dalam musyawarah desa dan musyawarah perencanaan pembangunan desa.

2. Pemerintah Desa perlu untuk mengoptimalkan potensi pertanian, baik dari anggaran APBDesa ataupun usaha BUMDesa. Hal ini perlu dilakukan agar petani tidak lagi menjual hasil pertanian kepada tengkulak, sehingga pendapatan petani dari penjualan hasil pertanian lebih maksimal. BUMDesa yang melayani penyaluran BPNT dapat mengambil beras dari petani yang ada di Desa Penatahan sehingga petani mendapatkan harga jual seharusnya.

3. Pemerintah pusat agar mengembangkan Indeks Desa Membangun dengan mempertimbangkan dimensi tata kelola pemerintahan desa dan keberadaan Pendapatan Asli Desa dalam menentukan tingkat kemandirian Desa

\section{UCAPAN TERIMAKASIH}

Kami mengucapkan terimakasih kepada Kepala Dinas Pemberdayaan Masyarakat dan Desa Kabupaten Tabanan beserta jajaran, Pendamping Desa di Kecamatan Penebel, Kepala Desa Penatahan beserta jajaran, Ketua BPD Desa Penatahan, serta warga Desa Penatahan yang telah bersedia meluangkan waktu memberikan informasi yang berkaitan dengan penelitian ini sehingga artikel ini dapat terselesaikan.

\section{DAFTAR PUSTAKA}

Bachrein, S. (2010). STRATEGI DAN KEBIJAKAN PEMBANGUNAN PERDESAAN Developing Village Approach in West Java : Rural Development Policy and Strategy. IAARD E-Journal, 8(2), 133-149. http://ejurnal.litbang.pertanian.go.id/index.php/akp/article/view/4227/3567

Bakti, H. S. (2018). Identifikasi Masalah Dan Potensi Desa Berbasis Indek Desa Membangun (Idm) Di Desa Gondowangi Kecamatan Wagir Kabupaten Malang. Wiga : Jurnal Penelitian IImu Ekonomi, 7(1), 1-14. https://doi.org/10.30741/wiga.v7i1.331

Fauzi, G. M., \& Hendrakusumah, E. (2019). Arahan Pengembangan Desa Bagawat Menuju Desa Mandiri berdasarkan Indeks Desa Membangun ( IDM ) Direction of Rural Development Bagawat to The Village Independent according to The Berdasarkan data dari Buku Kuningan kemiskinan Desa, Pengentasan Daerah Tert. Idm, 59-66.

Muhtarom, Kusuma, N., \& Purwanti, E. (2018). Village Index Analysis Building to Know The Village Development In Gadingrejo District of Pringsewu District. Inovasi Pembangunan : Jurnal Kelitbangan, 6(02), 179-190. https://doi.org/10.35450/jip.v6i02.96

Nur Arifah, M., \& Kusumastuti, N. (2019). Strategi Mempercepat Pembangunan Desa Mandiri: Studi Di Desa Kemadang Gunungkidul. Jurnal Pemberdayaan Masyarakat: Media Pemikiran Dan Dakwah Pembangunan, 2(1), 169-188. https://doi.org/10.14421/jpm.2018.021-09

Ra'is, D. U., \& Rini, Y. T. (2018). Analisa Peran Partisipatif Dan Akuntabilitas Perencanaan Pembangunan Desa (Studi Kasus Desa Sumberngepoh Kecamatan Lawang Kabupaten Malang). Reformasi, 8(2), 143. https://doi.org/10.33366/rfr.v8i2.1101

Ramdhani, A. R. M. A. (2016). Konsep Umum Pelaksanaan Kebijakan Publik. Jurnal Publik, Vol 11(January), 1-12. https://journal.uniga.ac.id/index.php/JPB/article/download/1/1

Setyowati, E. (2019). Tata Kelola Pemerintahan Desa Pada Perbedaan Indeks Desa Membangun (IDM): Studi Tiga Desa Di Kabupaten Malang. Jispo, 9(2), 170-188.

Sidik, F. (2015). Menggali Potensi Lokal Mewujudkan Kemandirian Desa. JKAP (Jurnal Kebijakan Dan Administrasi Publik), 19(2), 115. https://doi.org/10.22146/jkap.7962

Tay, D. S. R., \& Rusmiwari, S. (2019). Implementasi Kebijakan Pembangunan Berkelanjutan. JISIP: Jurnal IImu Sosial dan IImu Politik, 8(4), 217-222. https://publikasi.unitri.ac.id/index.php/fisip/article/view/1950

Solichin. (2017). EVALUASI KEBIJAKAN UU NOMOR 6 TAHUN 2014 TENTANG DESA (Studi Pelaksanaan Alokasi Dana Desa (ADD) di Desa Kembang Seri Kabupaten Bengkulu 
Tengah). 6(3), 69-78.

Suryono, A. (2010). Dimensi-Dimensi Prima Teori Pembangunan. Malang:UB Press 